(2) Open Access Full Text Article

\title{
Computational and Pharmacological Investigation of (E)-2-(4-Methoxybenzylidene)Cyclopentanone for Therapeutic Potential in Neurological Disorders
}

This article was published in the following Dove Press journal:

Drug Design, Development and Therapy

\author{
Sabah Farooq' \\ Arif-ullah Khan' \\ Muhammad Shahid Iqbal (D) ${ }^{2}$ \\ 'Riphah Institute of Pharmaceutical \\ Sciences, Riphah International University, \\ Islamabad, Pakistan; ${ }^{2}$ Department of \\ Clinical Pharmacy, College of Pharmacy, \\ Prince Sattam Bin Abdulaziz University, \\ Alkharj, Saudi Arabia
}

Purpose: This study involved the computational and pharmacological evaluation of (E)-2(4-methoxybenzylidene)cyclopentan-1-one (A2K10).

Methods: In silico studies were conducted through virtual screening. Morris water and Ymaze tests were conducted to evaluate Alzheimer's disease. Acute epilepsy haloperidol,and hyperalgesia were used to calculate the epilepsy model, with Parkinson's disease and mechanical allodynia at a dose of $1-10 \mathrm{mg} / \mathrm{kg}$ in the mouse model.

Results: A2K10 exhibited the highest binding affinity against $\alpha_{7}$ nicotinic acetylcholine receptors $(-256.02 \mathrm{kcal} / \mathrm{mol})$. A2K10 decreased escape latency in the Morris water test during different trials. In the Y-maze test, A2K10 dose-dependently increased spontaneous alteration behavior, with maximum effect of $75.5 \% \pm 0.86 \%$. Furthermore, A2K10 delayed onset of pentylenetetrazole-induced myoclonic jerks and tonic-clonic seizures and decreased duration of tonic-clonic convulsions in mice, with maximum effect of $93.8 \pm 5.30,77.8 \pm 2.91$, and $12.9 \pm 1.99$ seconds, respectively. In the haloperidol-induced Parkinson's disease model, A2K10 significantly prolonged hanging time and reduced tardive dyskinesia. Moreover, A2K10 extended latency in hot-plate hyperalgesia and increased the paw-withdrawal threshold in mechanical allodynia. In toxicity studies, no mortality was observed.

Conclusion: Overall, the results indicated that A2K10 has potential as an anti-Alzheimer's, antiepileptic, antiparkinsonian, and analgesic therapeutic compound.

Keywords: computational pharmacology, anti-Alzheimer, antiepileptic, antiparkinsonism , analgesic

\section{Introduction}

In developing countries, neurological disorders contribute to more than $6 \%$ of the global burden of diseases, a major cause of morbidity and mortality worldwide. ${ }^{1}$ The human body can be protected from the harmful consequences of reactive oxygen species by natural antioxidants, thus preventing the incidence of many chronic disorders. One of the most common neurodegenerative disorders in elderly people is Alzheimer's disease (AD). It primarily involves loss of memory, and in the nucleus basalis of Meynert, cholinergic neurons are almost completely destroyed. ${ }^{2}$ In the US, it is considered the sixth-leading cause of death and disability.

Epilepsy is characterized by periodic and involuntary seizures that may or may not be followed by uncontrolled body movements called convulsions. More than 50
Correspondence: Arif-ullah Khan Riphah Institute of Pharmaceutical Sciences, Riphah International University, 7th Avenue, Sector G-7/4, Islamabad, Pakistan

Tel +92-51-289-1835-38

Fax +92-5I-289I47I, 2890690

Email arif.ullah@riphah.edu.pk 
million people in the world are suffering from epilepsy, about $80 \%$ of these from low- and middle-income countries. ${ }^{3}$ Parkinson's disease (PD) is a movement disorder characterized by loss of dopaminergic neurons in the substantia nigra followed by muscular rigidity, bradycardia, and resting tremors; however its cause still remains unknown. Recently, PD has become less prevalent in Eastern countries due to genetic and environmental factors. Nevertheless, PD incidence is high among Africans, Americans, and Japanese. ${ }^{4}$

Neuropathic pain is one of most serious complications associated with chemotherapy. About 80\%-90\% patients receiving chemotherapeutic drugs experience peripheral neuropathy. ${ }^{5}$ The (E)-2-(4-methoxybenzylidene)cyclopentan-1-one investigated in present research project is an analogue of curcumin. The chemical name of curcumin is 1,7-bis(4-hydroxy-3-methoxyphenyl)-1,6-heptadiene-3,5dione, and it is obtained from the rhizome of Curcuma longa through different methods. Antitumor, antiviral, anti-inflammatory, antibacterial, anticoagulant, antifungal, and antioxidant effects of curcumin have been reported. ${ }^{6}$ (E)-2-(4-methoxybenzylidene)cyclopentan-1-one (A2K10) has already been synthesized and chemically characterized. An ionic liquid dimethylammonium dimethylcarbamate (DIMCARB)--catalyzed reaction was developed for the synthesis of monoarylidene cyclopentanone, which was used as an intermediate for the synthesis of A2K10. Reaction was performed by using a catalytic amount of DIMCARB in green solvent $\left(\mathrm{H}_{2} \mathrm{O}+\mathrm{EtOH}\right)$. DIMCARB is an adduct of $\mathrm{CO}_{2}$ and dimethylamine. The $\mathrm{A} 2 \mathrm{~K} 10$ obtained by this reaction was approximately $98 \%$ pure. ${ }^{7}$ In this research, we investigated A2K10 for its antioxidant, anti-AD, antiepileptic, anti-PD, and analgesic activities by employing in silico, in vitro, and in vivo techniques to explore its therapeutic potential in various neurological disorders. The chemical structure of A2K10 is shown in Figure 1.

\section{Methods}

\section{Chemicals}

Diazepam (Valium, $10 \mathrm{mg} / 2 \mathrm{~mL}$ injection) was obtained from Roche Pharmaceuticals. Cisplatin, levodopa, haloperidol, scopolamine, ascorbic acid, methanol, normal saline, ethanol, pentylenetetrazole (Ptz), and dimethyl sulfoxide (DMSO) were purchased from Sigma-Aldrich. All chemicals used were of analytic grade.

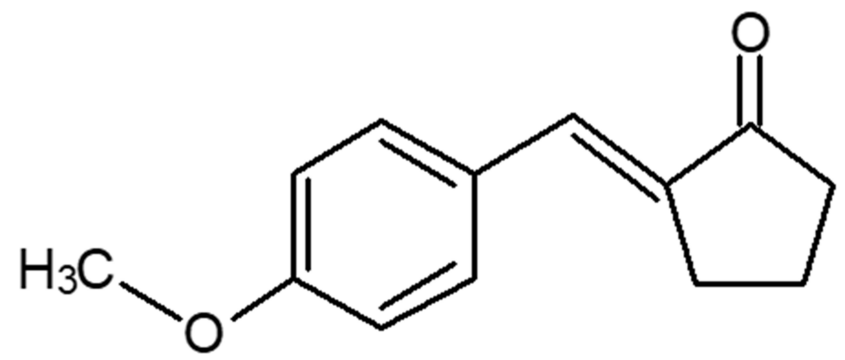

Figure I Chemical structure of (E)-2-(4-methoxybenzylidene)cyclopentan-I-one (A2KI0).

\section{Animals}

Adult BALB/c mice of either sex weighing 25-30 g were housed in a controlled temperature $\left(22^{\circ} \mathrm{C}-25^{\circ} \mathrm{C}\right)$. Animals were kept in clean plastic cages and maintained on a standard diet with water ad libitum. Animals were divided into various groups. Experiments were carried out in accordance with the guidelines of the Institute of Laboratory Animal Resorces, Commission on Life Sciences University, National Research Council (1996), and approved by the Ethical Committee of Riphah Institute of Pharmaceutical Sciences (REC/RIPS/ 2017/012). ${ }^{8}$

\section{Computational Study}

Molecular docking of test compounds was carried out to study therapeutic effects, focusing on good binding affinity at target sites. The three-dimensional structure of the test compound (A2K10) was drawn with Discovery Studio Visualizer (DSV). After selection of possible targets,3-D structures of targets/ receptors/macromolecules were taken from the RCSB Protein Data Bank (PDB; https://www.rcsb.org/pdb) and modified with DSV software. The PubChem database was used to obtain the structures of different standard drugs (https://pub chem.ncbi.nlm.nih.gov/search), which were then modified in DSV to get 3-D structures. PatchDock was used to study the binding affinity of A2K10 and standard drugs with targets based on their atomic contact energy (ACE; kcal $/ \mathrm{mol}$ ). $\mathrm{A} 2 \mathrm{~K} 10$ were docked against targets involved in AD: acetylcholinesterase (AChE; PDB ID 2WHP), butyrylcholinesterase (BuChE; PDB ID 1P0Q), N-methyl-D-aspartate (NMDA; PDB ID 5B3J), catechol-O-methyltransferase (COMT; PDB ID 5LSA), and $\beta$-secretase (BACE; PDB ID 6EJ2).Reference drugs against these targets were tacrine (PubChem CID 1935), tolcapone (PubChem CID 4659569), and donepezil (PubChem CID 3152). Targets involved in epilepsy include dual-specificity protein phosphatase 13 (DUSP13; PDB ID 2PQ5), $\gamma$-aminobutyric acid type A (GABA $A$; PDB ID 6A96), 
calcium release-activated calcium channel (Orai; PDB ID 4HKS). Reference drugs used against these targets were carbamazepine (PubChem CID 2554), diazepam (PubChem CID 3016), and phenytoin (PubChem CID 1775). A2K10 was also docked against multiple targets involved in $\mathrm{PD}$, including dopamine receptor $\mathrm{D}_{2}$ (PDB ID 6CM4), GABA ${ }_{B}$, (PDB ID 4MS3), histamine receptor $\mathrm{H}_{1}$ (PDB ID 3RZE) and muscarinic receptor $\mathrm{M}_{1}$ (PDB ID $5 \mathrm{CXV})$. Reference drugs used against these targets were levodopa (PubChem CID 6047), valproic acid (PubChem CID 4659569), promethazine (PubChem CID 4927), and orphenadrine (PubChem CID 4601). Targets modulating pain taken into account during this study included phospholipase $\mathrm{A}_{2}\left(\mathrm{PLA}_{2}\right.$; PDB ID $\left.3 \mathrm{U} 8 \mathrm{~B}\right), \alpha_{7}$ nicotinic receptors $\left(\alpha_{7} \mathrm{nAChRs}\right.$; PDB, ID 3SQ9),TLR4, PDB ID 3FXI), TNF $\alpha$ (PDB ID 2TNF), PPAR $\gamma$ (PDB ID 6ENQ), cyclooxygenase 2 (COX2, PDB ID 5KIR), and $\alpha_{4} \beta_{2}$ receptors (PDB ID 5KXI). 4-Methoxy benzoic acid (PubChem CID 7478), acetylcholine (PubChem CID 101,536,190), ibudilast (PubChem CID 3671), aspirin (PubChem CID 2244), and pioglitazone (PubChem CID 4829) were used as reference drugs. XML files of structures of standard drugs were converted to PDB format using Open Babel JUI software.

\section{Antioxidant Activity}

A test-sample solution was prepared in DMSO using ascorbic acid as a standard. DPPH solution was prepared in methanol and added in dilutions to $\mathrm{A} 2 \mathrm{~K} 10$. Then, the mixture of DMSO solution and dilutions were placed in the dark for 30 minutes. Ultraviolet spectrophotometry was used to measure absorbance at $517 \mathrm{~nm} .{ }^{9}$ Free-radical scavenging was calculated:

$\% \mathrm{DPPH}$ radical scavenging $=[(\mathrm{A}-\mathrm{B}) / \mathrm{A}] \times 100$

where, $\mathrm{A}$ is absorbance of control and B absorbance of test sample.

\section{Anti-Alzheimer's Models Morris Water Maze (MWM) Test}

Mice were divided into five groups $(n=5)$. Group I was injected with normal saline $(10 \mathrm{~mL} / \mathrm{kg})$ intraperitoneally (IP) and used as negative control. Groups II, III, and IV were given various doses of test compound (1,3, and $10 \mathrm{mg}$ / $\mathrm{kg}$ respectively). Group V was given donepezil ( $3 \mathrm{mg} / \mathrm{kg} \mathrm{IP}$ ) once/day for 5 days and used as positive control. On the first day, swimming training was given to all mice for 60 seconds without a platform. With the platform in place, the mouse was given trial sessions for 4 days. The mouse was allowed to remain on the platform for 10 seconds after it had located it. If the mouse failed to locate the platform within 120 seconds, it was placed on it for 10 seconds and then removed. On day 5, mice were individually subjected to a probe-trial session without a platform. Each mouse was allowed to swim for 120 seconds to search for it, and escape latencywas determined. ${ }^{10}$ Anti-AD activity was indicated when there is a decrease in escape latency.

\section{Y-Maze Test}

A Y-maze apparatus with three arms was used. Grouping of mice was the same as in the MWM. At 30 minutes after receiving saline, A2K10, or donepezil, each mouse was placed at the center of the apparatus, then allowed to move freely for three sessions ( 8 minutes each). The successive entry of the mice into three arms in overlapping triplet sets was termed spontaneous alteration behavior. Scopolamine $(2 \mathrm{mg} / \mathrm{kg}$ ) was also used in a group to check results in the diseased group. Alteration behavior percentage was calculated as: (successive triplet sets [entries into three arms consecutively]/total number of entries -2] $\times 100 .^{11}$ AntiAD activity was indicated by an increase in alteration behavior percentage.

\section{Antiepileptic Assays}

Mice were divided into five groups $(n=5)$. Group I was injected with normal saline (10 mL/kg IP) and used as negative control. Groups II, III, and IV were given various doses of $\mathrm{A} 2 \mathrm{~K} 10$ (1, 3, and $10 \mathrm{mg} / \mathrm{kg}$ respectively). Group V received diazepam $(1 \mathrm{mg} / \mathrm{kg} \mathrm{IP})$ and was used as positive control. At 30 minutes after injection of saline, A2K10, or diazepam, Ptz) was injected IP at a dose of $90 \mathrm{mg} / \mathrm{kg}$ and each mouse observed for 30 minutes for the onset of myoclonic and tonic-clonic seizures and time span of tonicclonic seizures. Drugs that showed anticonvulsant-effect delays in the onset of these seizures and reduced the duration of tonic-clonic convulsions. ${ }^{12}$ The mortality of mice was also observed: mortality $=$ number of mice dead after seizures/total number of mice used $\times 100$ ).

\section{Anti-Parkinsonism Techniques Hanging Test}

Mice were divided into six groups $(n=6)$. Group I was injected with normal saline $(10 \mathrm{~mL} / \mathrm{kg} \mathrm{IP})$ and was used as negative control. Group II was given haloperidol $(1 \mathrm{mg} / \mathrm{kg}$ IP). Groups III, IV, and V were administered (1, 3 and 10 $\mathrm{mg} / \mathrm{kg} \mathrm{IP}$, respectively) for 1 week. Group VI was given IPthe positive control - levodopa $(30 \mathrm{mg} / \mathrm{kg}$ IP). Saline, 
test compound, and levodopa were given 30 minutes before the administration of haloperidol. Tests were performed on day 8 . To check neuromuscular strength, mice were lifted by their tails, placed on a horizontal grid, and supported until they grabbed the grid with both their foreand hind-paws. The grid was inverted to allow mice to hang upside down for 30 seconds, Five chances were given to animals with 1-minute intervals, and maximum hanging time was recorded. ${ }^{13}$

\section{Tardive Dyskinesia}

Tardive dyskinesia means rapid vacuous chewing movements (VCMs). Grouping of mice was the same as in the hanging test.Mice were placed individually in small cages for observation of oral dyskinesia. Ten minutes was given to animals to get used to the experimental cage. VCMs were measured by the number of mouth openings in the vertical plane. Under the floor and behind the back wall, mirrors were positioned and the animal faced away from observer for measurement of oral dyskinesia for 5 minutes. ${ }^{13}$

\section{Cisplatin-Induced Neuropathic Pain Thermal Hyperalgesia}

Animals were divided into six groups $(\mathrm{n}=6)$. Group I was administered normal saline $(10 \mathrm{~mL} / \mathrm{kg}$ IP) as negative control. Group II was injected with cisplatin $(5 \mathrm{mg} / \mathrm{kg}$ IP) once a week for 25 days (days $0,8,15$, and 22). Groups III, IV, and V were given $\mathrm{A} 2 \mathrm{~K} 10$ (1, 3, and 10 $\mathrm{mg} / \mathrm{kg}$ IP, respectively). Group VI received tramadol hydrochloride $(30 \mathrm{mg} / \mathrm{kg} \mathrm{IP})$ as positive control. A2K10 was injected from day 8 to day 25. Cisplatin was injected 30 minutes before A2K10. Tests were performed on day 0 and from day 8 to day 25 , with intervals of 4 days. A hot plate maintained at $54^{\circ} \mathrm{C} \pm 0.5^{\circ} \mathrm{C}$ was used to measure latency A 30-seconds cutoff was used to avoid paw-tissue damage.

\section{Mechanical Allodynia}

In response to mechanical stimulation, paw-withdrawal threshold (PWTs) were measured using the up-and-down method. Grouping of mice was the same as in thermal hyperalgesia. Mice were placed in individual cages on an elevated wire-mesh platform and allowed to get used to the apparatus for at least 30 minutes. Force was be applied using a von Frey hair kit to the mid-plantar region of each hindpaw. Baseline readings were obtained before experimental testing. ${ }^{14}$

\section{Acute Toxicity}

A group of five mice was administered $500 \mathrm{mg} / \mathrm{kg}$ A2K 10 IP. Mice were observed for 24 hours for any mortality. ${ }^{15}$

\section{Statistical Analysis}

Data were analyzed and are expressed as mean \pm SEM. One-way ANOVAs were utilized to analyze results, followed by Tukey's post hoctest. $p<0.05$ was taken as significantly significant. Bar charts were assessed using GraphPad Prism 6.

\section{Results}

\section{Docking Evaluation}

Computational analysis of A2K10 was carried out against various targets involved in different neurological diseases, including $\mathrm{AD}$, epilepsy, $\mathrm{PD}$, and neuropathic pain. It showed different values of ACE with these targets, which showed its binding affinity. The best interaction was against $\alpha_{7} \mathrm{nAChR}$, with good interactions against PPAR $\gamma, T N F \alpha$, and COX2. The ACE value against $\alpha 7 \mathrm{nAChR}$ was $-256.02 \mathrm{kcal} / \mathrm{mol}$. Interactions of A2K10 and acetylcholine against $\alpha_{7} \mathrm{nAChRis}$ are presented in Figure 2. ACE values, H-bonds, and residues forming $\mathrm{H}$ bonds are also presented in Tables 1-3. Targets, reference drugs, and interactions are presented in Figures S1-S21.

\section{DPPH Free Radical-Scavenging Effect}

At concentrations of 1, 3, 10,100,300,700, and 1,000, $\mathrm{gg} /$ $\mathrm{mL}, \mathrm{A} 2 \mathrm{~K} 10$ exhibited free radical-scavenging effects of $0.82 \% \pm 0.14 \%, \quad 1.96 \% \pm 0.44 \%, \quad 4.05 \% \pm 0.01 \%, \quad 7.20 \%$ $\pm 0.44 \%, \quad 8.68 \% \pm 2.33 \%, \quad 10.95 \% \pm 2.56 \%$, and $18.48 \%$ $\pm 0.006 \%$, respectively. Ascorbic acid at concentrations of $1,3,10,100,300,700$, and $1,000 \mu \mathrm{g} / \mathrm{mL}$ caused $2.16 \%$ $\pm 0.18 \%, \quad 4.24 \% \pm 0.33 \%, \quad 4.31 \% \pm 0.45 \%, \quad 15.95 \% \pm 0.72 \%$, $64.18 \% \pm 0.14 \%, 92.22 \% \pm 0.02 \%$, and $93.29 \% \pm 0.09 \%$ free radical-scavenging effects, respectively (Figure 3).

\section{Effect on Escape Latency}

A2K10 dose-dependently $(1-10 \mathrm{mg} / \mathrm{kg})$ decreased escape latency in the MWM. In the saline $(10 \mathrm{~mL} / \mathrm{kg})$-treatment group, escape latency in trials $1-3$ was $28.4 \pm 0.74,23.6$ \pm 0.60 , and $19.9 \pm 0.72$ seconds, respectively. Treatment with A2K10 $(1 \mathrm{mg} / \mathrm{kg})$ reduced escape latency in trials $1-3$ to $18.6 \pm 0.61$ ( $p<0.001$ vs saline group), $16.4 \pm 0.88$ $(p<0.001$ vs saline group) and $13.7 \pm 0.41$ ( $p<0.001$ vs saline group) seconds, respectively. Treatment with A2K10 (3 mg/kg) decreased escape latency in trials 1-3 

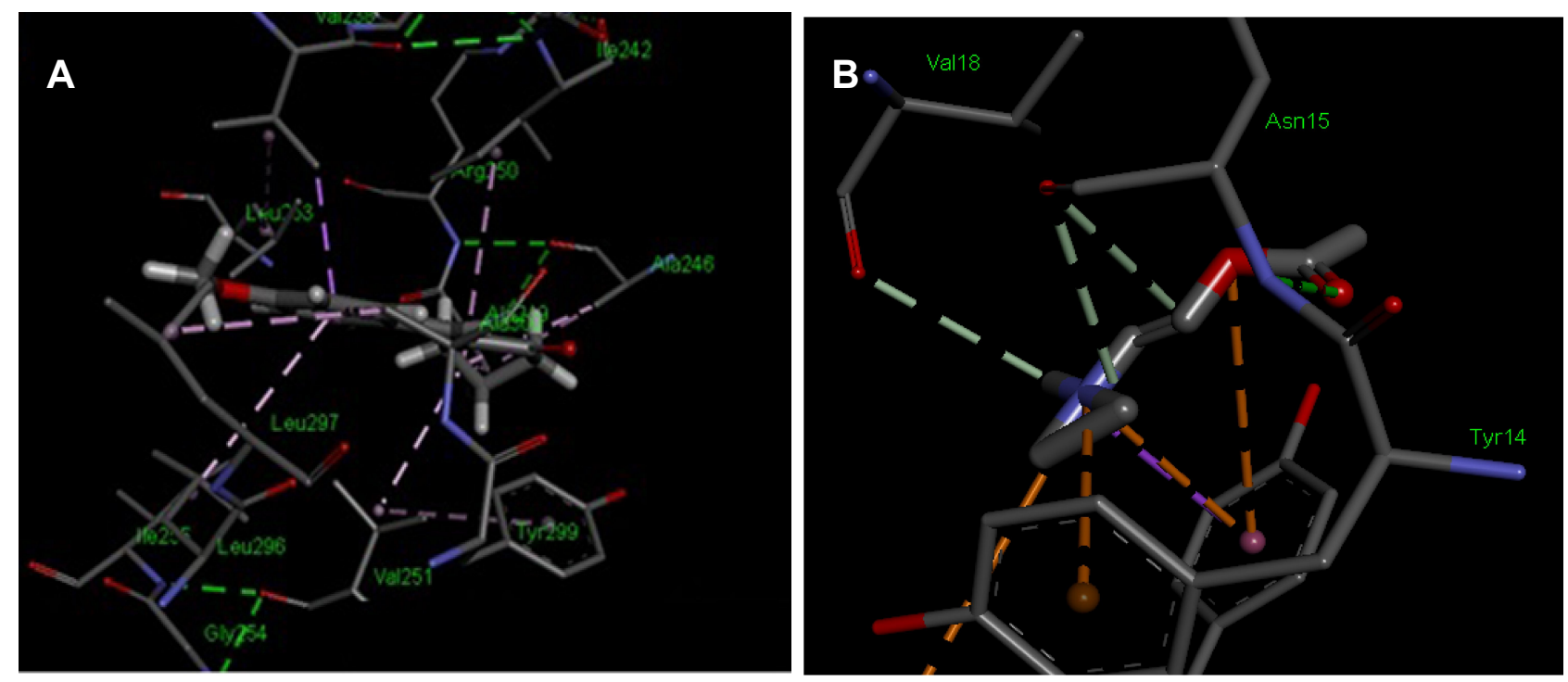

\section{Interactions}
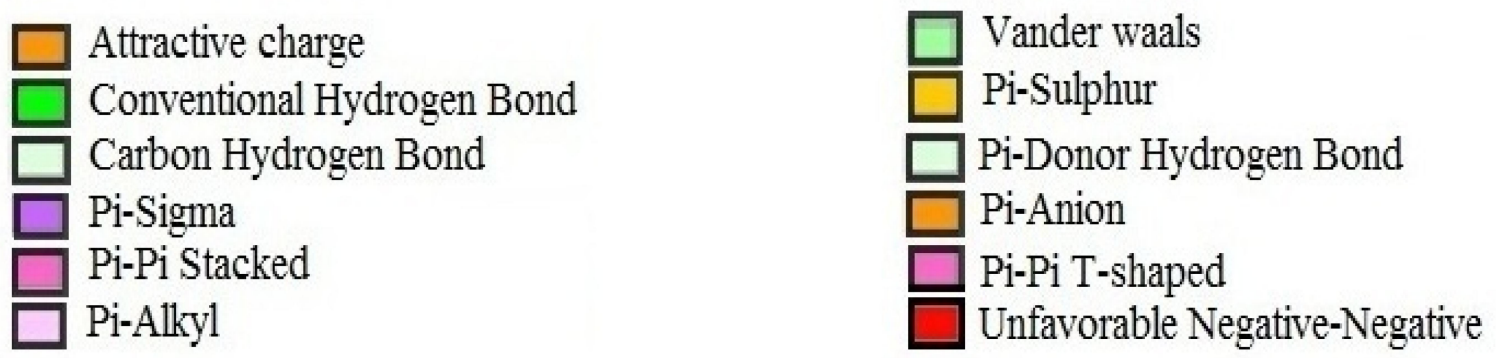

Figure 2 (A, B) Interactions of (E)-2-(4-methoxybenzylidene)cyclopentan-I-one (A2K10) and acetylcholine with $\alpha_{7}$ nicotinic acetylcholine receptors ( $\alpha_{7}$ nAChRs), respectively, drawn with Discovery Studio Visualizer 2016.

to $15.9 \pm 0.46 \quad(p<0.001$ vs saline group $), \quad 13.5 \pm 0.48$ $(p<0.001$ vs saline group) and $11.4 \pm 0.66(p<0.001$ vs saline group) seconds, respectively. Treatment with A2K10 (10 mg/kg) decreased escape latency in trials $1-3$ to $11.2 \pm 0.78$ ( $p<0.001$ vs saline group), $8.4 \pm 0.51(p<0.001$ vs saline group), and $7.6 \pm 0.42(p<0.001$ vs saline group) seconds, respectively. For donepezil $(3 \mathrm{mg} / \mathrm{kg})$, escape latency in trials $1-3$ was recorded as $22.0 \pm 0.95(p<0.001$

Table I ACE Values (kcal/mol), H-bonds, and Residues Forming H-bonds of Best-Docked Poses of (E)-2-(4-methoxybenzylidene) cyclopentan-I-one (A2KI0) and Standard Drugs with AcetylcholinestErase (AChE), Butyrylcholinesterase (BuChE), N-methyl-Daspartate (NMDA), catechol-O-methyltransferase (COMT), and $\beta$-secretase (BACE)

\begin{tabular}{|c|c|c|c|c|c|c|c|c|}
\hline \multirow[t]{2}{*}{ Target } & \multicolumn{3}{|l|}{ A2K 10} & \multirow[b]{2}{*}{ Binding Residue } & \multicolumn{4}{|c|}{ Standard Drugs } \\
\hline & PDB ID & $\begin{array}{l}\text { E-value } \\
\text { (kcal/mol) }\end{array}$ & H-bonds & & Standard & $\begin{array}{l}\text { E-value } \\
\text { (kcal/mol) }\end{array}$ & H-bonds & Binding Residue \\
\hline AChE & $2 \mathrm{WHP}$ & -140.26 & I & Ser203 & Tacrine & -279.17 & 2 & $\begin{array}{l}\text { Ser203 } \\
\text { Tyr337 }\end{array}$ \\
\hline BuChE & IPOQ & -101.13 & 0 & Nil & Tacrine & -139.31 & 0 & Nil \\
\hline NMDA & 5B3] & -209.07 & 1 & Ser 170 & Tacrine & -165.25 & I & Thr324 \\
\hline СОMT & $5 L S A$ & -188.47 & 0 & Nil & Tolacapone & -175.78 & 1 & Ser 169 \\
\hline BACE & $6 \mathrm{EJ} 2$ & -125.76 & 0 & Nil & Donepezil & -263.79 & 4 & Gly639, Tyr480, Trp485, Asp637 \\
\hline
\end{tabular}

Abbreviations: Ser, serine; Tyr, tyrosine; Thr, threonine; Asp, aspartic acid; Gly, glycine; Trp, tryptophan. 
Table 2 ACE Values (kcal/mol), H-bonds, and Residues Forming H-bonds of Best-Docked Poses of (E)-2-(4-methoxybenzylidene) cyclopentan-I-one $(\mathrm{A} 2 \mathrm{KIO})$ and standard drugs with dual-specificity protein phosphatase 13 (DUSPI3), $\gamma$-aminobutyric acid A $\left(\mathrm{GABA}_{\mathrm{A}}\right)$, and Calcium Release-Activated Calcium Channel (Orai)

\begin{tabular}{|c|c|c|c|c|c|c|c|c|}
\hline \multirow[t]{2}{*}{ Target } & \multicolumn{3}{|l|}{ A2K 10} & \multirow[b]{2}{*}{ Binding Residue } & \multicolumn{4}{|c|}{ Standard Drugs } \\
\hline & PDB ID & $\begin{array}{l}\text { E-value } \\
\text { (kcal/mol) }\end{array}$ & H-bonds & & Standard & $\begin{array}{l}\text { E-value } \\
\text { (kcal/mol) }\end{array}$ & H-bonds & Binding Residue \\
\hline DUSPI3 & 2PQ5 & -114.94 & 0 & Nil & Carbamazepine & -232.24 & 2 & $\begin{array}{l}\text { Ala80 } \\
\text { Gln84 }\end{array}$ \\
\hline $\mathrm{GABA}_{\mathrm{A}}$ & $6 \mathrm{~A} 96$ & -181.40 & 0 & Nil & Diazepam & -231.26 & 0 & Nil \\
\hline Orai & $4 \mathrm{HKS}$ & -155.88 & 1 & Tyr243 & Phenytoin & -251.67 & 1 & Thr252 \\
\hline$D_{2}$ & $6 \mathrm{CM} 4$ & $-|74.5|$ & 0 & Nil & Levodopa & -208.09 & 1 & Thr205 \\
\hline $\mathrm{GABA}_{\mathrm{B}}$ & $4 M S 3$ & -142.94 & 3 & $\begin{array}{l}\text { Thr } 199 \\
\text { Gln } 197\end{array}$ & Valproic acid & -138.68 & 2 & Asp214, Asp229 \\
\hline $\mathrm{H}_{1}$ & 3RZE & -180.28 & 0 & Nil & Promethazine & -325.18 & 0 & Nil \\
\hline$M_{1}$ & $5 \mathrm{CXV}$ & -181.26 & 1 & Thr366 & Orphenadrine & -235.21 & 0 & Nil \\
\hline
\end{tabular}

Abbreviations: Tyr, tyrosine; Asn, aspartic acid; Ser, serine; Thr, threonine; Arg, arginine; Leu, leucine; Val, valine.

Table 3 ACE Values (kcal/mol), H-bonds, and Residues Forming H-bonds of Best-Docked Poses of (E)-2-(4-methoxybenzylidene) cyclopentan-I-one (A2K10) and standard drugs with Phospholipase $A_{2}\left(P_{2} A_{2}\right), \alpha_{7}$ Nicotinic Acetylcholine Receptor ( $\left.\alpha_{7} n A C h R\right)$, TLR4, TNF $\alpha$, PPAR $\gamma$, Cyclooxygenase 2 (COX2), and $\alpha_{4} \beta_{2}$

\begin{tabular}{|c|c|c|c|c|c|c|c|c|}
\hline \multirow[t]{2}{*}{ Target } & \multicolumn{3}{|l|}{ A2K 10} & \multirow[b]{2}{*}{ Binding Residue } & \multicolumn{4}{|l|}{ Standard Drugs } \\
\hline & PDB ID & $\begin{array}{l}\text { E-value } \\
\text { (kcal/mol) }\end{array}$ & H-bonds & & Standard & $\begin{array}{l}\text { E-value } \\
\text { (kcal/mol) }\end{array}$ & H-bonds & Binding Residue \\
\hline $\mathrm{PLA}_{2}$ & $3 \cup 8 B$ & -34.97 & 0 & Nil & 4-methoxybenzoic acid & -155.06 & 1 & Tyr5I \\
\hline$\alpha_{7} \mathrm{nAChR}$ & 3SQ9 & -256.02 & 0 & Nil & Acetylcholine & -157.04 & 1 & Asn 15 \\
\hline TLR4 & $3 \mathrm{FXI}$ & -175.55 & 2 & Vall I3 & Ibudilast & -210.32 & 2 & Ser386 \\
\hline TNF $\alpha$ & $2 \mathrm{TNF}$ & -196.18 & 0 & Nil & Aspirin & -130.75 & 1 & Thrl19 \\
\hline $\operatorname{PPAR} \gamma$ & 6ENQ & -170.17 & 0 & Nil & Pioglitazone & -312.26 & 2 & $\begin{array}{l}\text { Arg443 } \\
\text { Leu442 }\end{array}$ \\
\hline $\operatorname{cox} 2$ & $5 K I R$ & -163.42 & 0 & Nil & Aspirin & -180.37 & 3 & Asn537 \\
\hline$\alpha_{4} \beta_{2}$ & $5 \mathrm{KXI}$ & -103.31 & 1 & Val45 & Acetylcholine & -173.14 & 1 & Val45 \\
\hline
\end{tabular}

Abbreviations: Ala, alanine; Gln, glutamine; Tyr, tyrosine; Thr, threonine; Gln, glutamine; Asp, aspartic acid.

vs saline group), $18.4 \pm 0.95$ ( $p<0.001$ vs saline group), and $14.9 \pm 0.95$ ( $p<0.001$ vs saline group) seconds, respectively (Figure 4).

\section{Effect on Alteration Behavior}

A2K10 dose-dependently (1-10 mg/kg) increased spontaneous alteration behavior of mice in the Y-maze. The saline $(10 \mathrm{~mL} / \mathrm{kg}$ )-treatment group showed alteration behavior of $49 \% \pm 1.26 \%$. Treatment with A2K10 $(1 \mathrm{mg} / \mathrm{kg})$ showed increased alteration behavior of $56.1 \% \pm 0.93 \%(p<0.001$ vs saline group). Treatment with A2K10 (3 mg/kg) showed increased alteration behavior of $63.2 \% \pm 1.26 \%(p<0.001$ vs saline group), while treatment with A2K10 $(10 \mathrm{mg} / \mathrm{kg})$ showed maximum alteration behavior of $75.5 \% \pm 0.86 \%$ ( $p<0.001$ vs saline group). The donepezil ( $3 \mathrm{mg} / \mathrm{kg}$ )-injected group showed alteration behavior of $64.5 \% \pm 0.81 \%$ $(p<0.001$ vs saline group), as presented in Figure 5 . A2K10 (10 mg/kg) increased spontaneous alteration behavior of mice in the Y-maze. The saline treatment group showed alteration behavior of $48.8 \% \pm 2.62 \%$, scopolamine $(2 \mathrm{mg} / \mathrm{kg}$ ) showed $25.9 \% \pm 0.96 \%$, A2K10 (10 mg/kg) showed $65.9 \% \pm 2.32 \%$, and donepezil showed alteration behavior of $74.02 \% \pm 1.80 \%$, as presented in Figure 6 .

\section{Effect on Number of Entries}

A2K10 dose-dependently $(1-10 \mathrm{mg} / \mathrm{kg})$ increased the number of entries in the Y-maze test. In group receiving saline $(10 \mathrm{~mL} / \mathrm{kg})$, the number of entries on days $1-3$ was $22.0 \pm 0.41,18.3 \pm 0.58$ and $16.8 \pm 0.40$, respectively. In the A2K10 (1 mg/kg) group, the number of entries on days 1- 


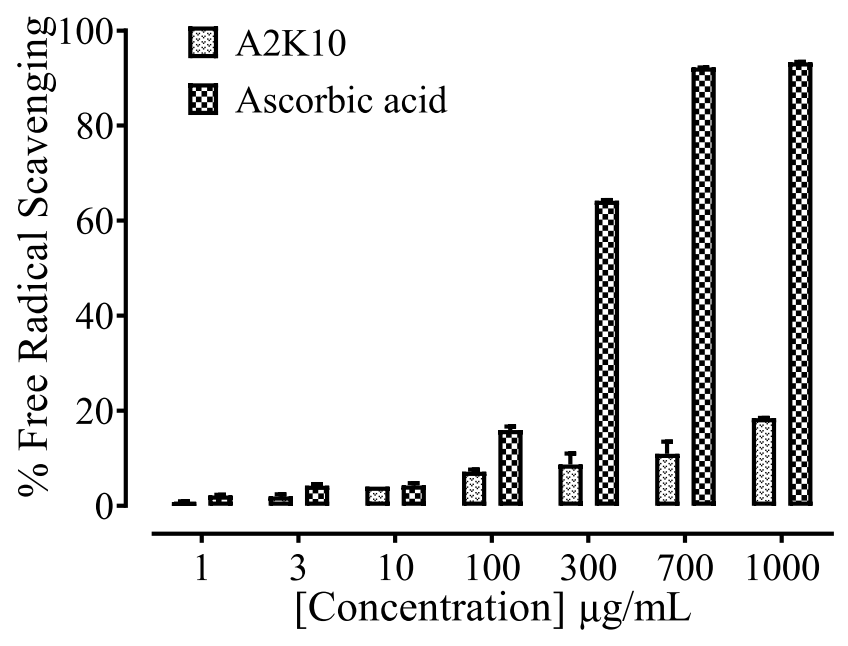

Figure 3 Bar chart showing inhibitory effect of (E)-2-(4-methoxybenzylidene) cyclopentan-I-one $(\mathrm{A} 2 \mathrm{KI})$ and ascorbic acid against DPPH free radical-scavenging activity. Values shown as means \pm SEM, $n=3-4$.
3 increased to $33.5 \pm 1.05$ ( $p<0.001$ vs saline group), 21.1 \pm 0.74 ( $p<0.001$ vs saline group), and $19.2 \pm 0.38$ ( $p<0.001$ vs saline group), respectively. In the A2K10 (3 mg/kg)injected group, the number of entries on days 1-3 increased to $34.3 \pm 0.51$ ( $p<0.001$ vs saline group), 26.5 \pm 0.55 ( $p<0.001$ vs saline group), and $23.2 \pm 0.58$ ( $p<0.001$ vs saline group), respectively. In the A2K10 (10 mg/kg)injected group, the number of entries on days 1-3 increased to $45.8 \pm 0.68$ ( $p<0.001$ vs saline group), 37.9 \pm 0.77 ( $p<0.001$ vs saline group), and $26.5 \pm 0.67$ ( $p<0.001$ vs saline group), respectively. In the donepezil (3 mg/kg)treated group, the number of entries on days 1-3 recorded was $26.1 \pm 0.49$ ( $p<0.001$ vs saline group), $24.4 \pm 0.99$ ( $p<0.001$ vs saline group), and $21.6 \pm 0.52$ ( $p<0.001$ vs saline group), respectively (Figure 7).

$\square$ Saline $(10 \mathrm{~mL} / \mathrm{Kg})$

曰 $\mathrm{A} 2 \mathrm{~K} 10(1 \mathrm{mg} / \mathrm{Kg})$

四 $\mathrm{A} 2 \mathrm{~K} 10(3 \mathrm{mg} / \mathrm{Kg})$

$\boldsymbol{\Delta} \mathrm{A} 2 \mathrm{~K} 10(10 \mathrm{mg} / \mathrm{Kg})$

B Donepezil $(3 \mathrm{mg} / \mathrm{Kg})$

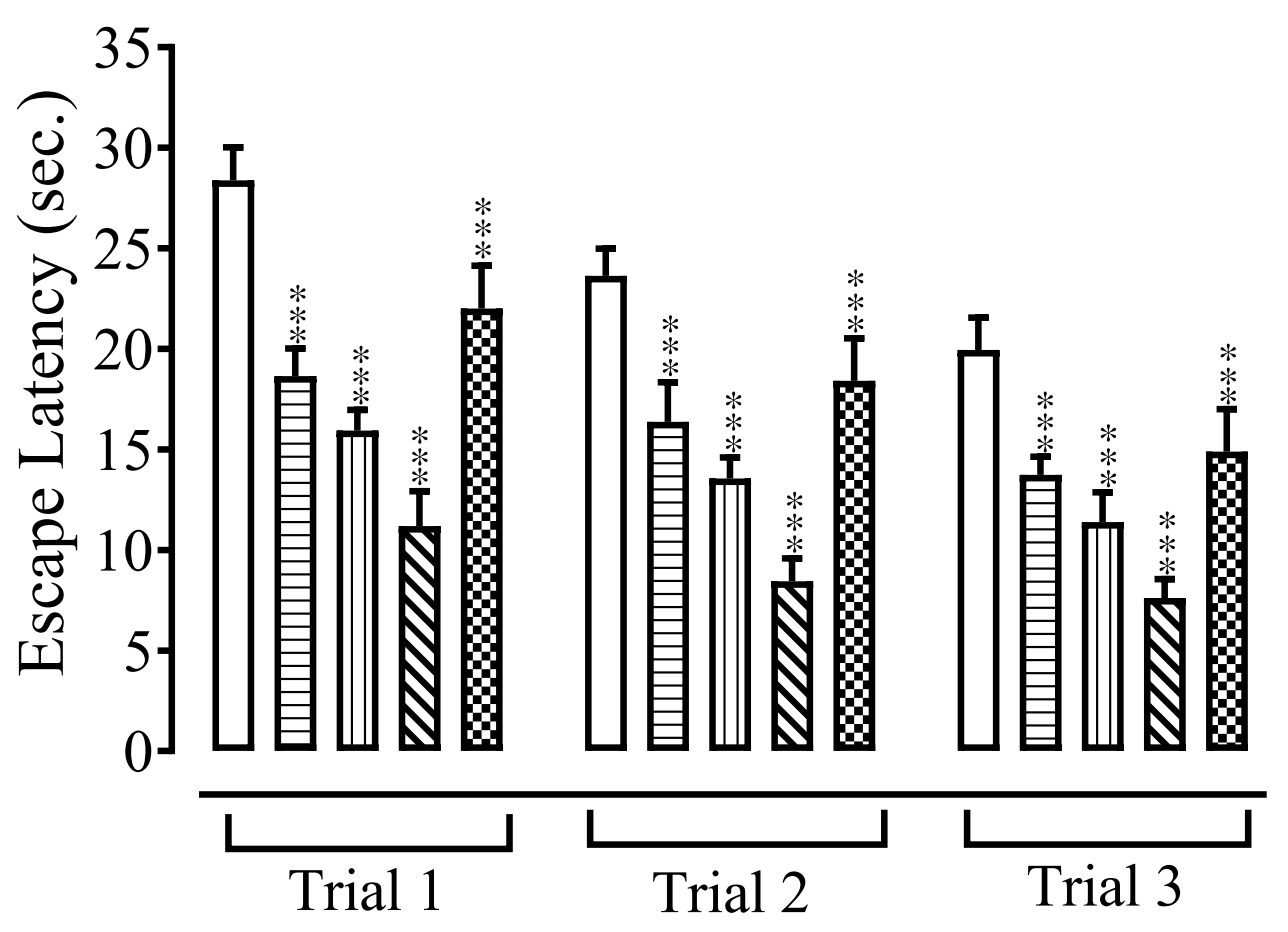

Figure 4 Bar chart showing effect of (E)-2-(4-methoxybenzylidene)cyclopentan-I-one (A2KI0) and donepezil on escape latency of mice in trials I, 2, and 3 in the Morris water maze (MWM) test. Data presented as means \pm SEM, $n=5$. $* * * p<0.00$ I vs saline group on one-way ANOVA with Tukey's post hoc test 

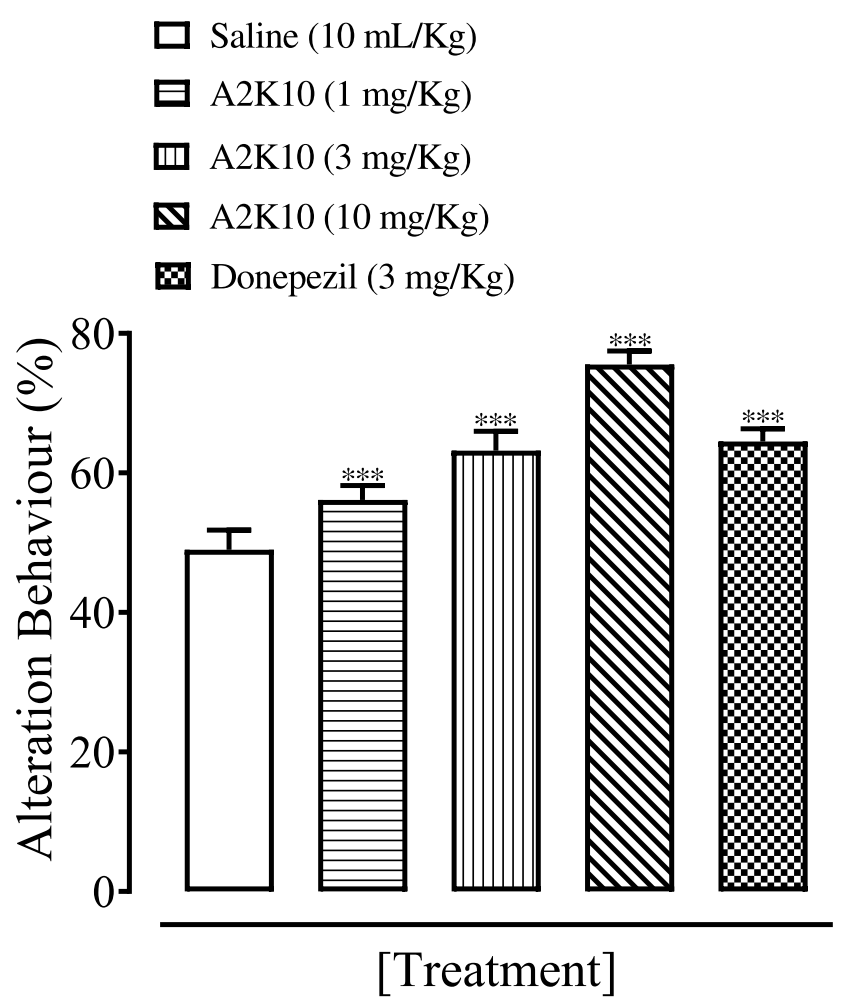

Figure 5 Bar chart showing effect of (E)-2-(4-methoxybenzylidene)cyclopentan- Ione $(\mathrm{A} 2 \mathrm{~K} 10)$ and donepezil on alterations in behavior of mice in the Y-maze test. Data presented as means \pm SEM, $n=5 . * * * p<0.001$ vs saline group on one-way ANOVA with Tukey's post hoc test.

\section{Effect on Ptz-Induced Seizures}

A2K10 dose-dependently (1-10 mg/kg) delayed onset of Ptz-induced myoclonic and tonic-clonic convulsions, decreased duration of tonic-clonic convulsions, and improved mortality. In the saline $(10 \mathrm{~mL} / \mathrm{kg})$-treatment group, onset of myoclonic, tonic-clonic convulsions, and duration of tonic-clonic convulsions were $16.8 \pm 5.28,19.8$ \pm 6.07 , and $43.5 \pm 5.21$ seconds, respectively. In the A2K10 (1 $\mathrm{mg} / \mathrm{kg}$ ) group, onset of myoclonic and tonic-clonic convulsions increased to $55.1 \pm 5.06$ and $64.4 \pm 1.76$ seconds $(p<0.001$ vs saline group), respectively, while duration of tonic-clonic convulsions decreased to $25.4 \pm 1.43$ seconds. In the $\mathrm{A} 2 \mathrm{~K} 10(3 \mathrm{mg} / \mathrm{kg})$ group, onset of myoclonic and tonic-clonic convulsions extended to $75.0 \pm 3.07$ and 77.8 \pm 2.91 seconds ( $p<0.001$ vs saline group), respectively, while duration of tonic-clonic convulsions decreased to $20.9 \pm 1.94$ seconds ( $p<0.05$ vs saline group). In the $\mathrm{A} 2 \mathrm{~K} 10$ $(10 \mathrm{mg} / \mathrm{kg})$-treated group, onset of myoclonic and tonicclonic convulsions extended to $93.8 \pm 5.29$ and $77.8 \pm 2.91$ seconds ( $p<0.001$ vs saline group), respectively, while duration of tonic-clonic convulsions decreased to $12.9 \pm 1.99 \mathrm{sec}-$ onds ( $p<0.001$ vs saline group). In the group treated with
Saline $(10 \mathrm{~mL} / \mathrm{Kg})$

Scopolamine $(2 \mathrm{mg} / \mathrm{Kg})$

III Scopolamine $(2 \mathrm{mg} / \mathrm{Kg})+\mathrm{A} 2 \mathrm{~K} 10(10 \mathrm{mg} / \mathrm{Kg})$

W Scopolamine $(2 \mathrm{mg} / \mathrm{Kg})+$ Donepezil $(3 \mathrm{mg} / \mathrm{Kg})$

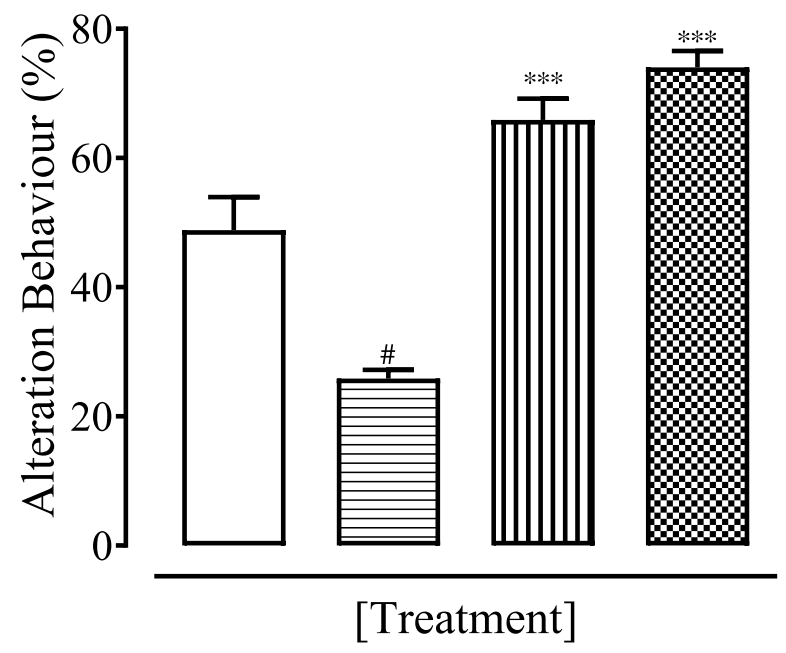

Figure 6 Bar chart showing effect of (E)-2-(4-methoxybenzylidene)cyclopentan-Ione $(\mathrm{A} 2 \mathrm{~K} 10)$ and donepezil on alterations in behavior of mice with scopolamineinduced amnesiain the Y-maze test. Data presented as means \pm SEM. ${ }^{\#} p<0.01$ vs saline group and $*^{*} p<0.001$ vs scopolamine group on one-way ANOVA with Tukey's post hoc test.

diazepam (1 mg/kg), onset of myoclonic and tonic-clonic convulsions extended to $90.9 \pm 6.59$ and $117.4 \pm 5.45$ seconds ( $p<0.001$ vs saline group) respectively, while duration of tonic-clonic convulsions decreased to $12.5 \pm 2.28$ seconds $(p<0.001$ vs saline group), as shown in Figure 8 . A2K10 at 1,3 , and $10 \mathrm{mg} / \mathrm{kg}$ decreased mortality rates to $80 \%(p<0.01$ vs saline group), $60 \%$ ( $p<0.001$ vs saline group), and $20 \%$ $(p<0.001$ vs saline group), respectively. In the group treated with diazepam $(1 \mathrm{mg} / \mathrm{kg})$, no mortality $(p<0.001$ vs saline group) was observed, as presented in Table 4.

\section{Effect on Hanging Time}

On the first day, there was no significant change seen in hanging time of mice, but A2K10 had caused a dosedependent $(1-10 \mathrm{mg} / \mathrm{kg})$ increase in hanging time by the eighth day. In the saline $(10 \mathrm{~mL} / \mathrm{kg})$-treatment group, hanging duration on the first and eighth days was 16.3 \pm 0.24 and $17.3 \pm 1.02$ seconds, respectively. In the group treated with haloperidol $(1 \mathrm{mg} / \mathrm{kg})$, hanging time on the first and eighth days had decreased to $8.8 \pm 0.34$ and 3.5 \pm 0.30 seconds ( $p<0.001$ vs saline group), respectively. In the A2K10 (1 mg/kg)-injected group, hanging time on the first and eighth days had increased to $7.5 \pm 0.47$ and 14.3 
$\square$ Saline $(10 \mathrm{~mL} / \mathrm{Kg})$

曰 $\mathrm{A} 2 \mathrm{~K} 10(1 \mathrm{mg} / \mathrm{Kg})$

四 A2K10 (3 mg/Kg)

$\boldsymbol{\nabla}$ A2K10 $(10 \mathrm{mg} / \mathrm{Kg})$

B Donepezil (3 mg/Kg)

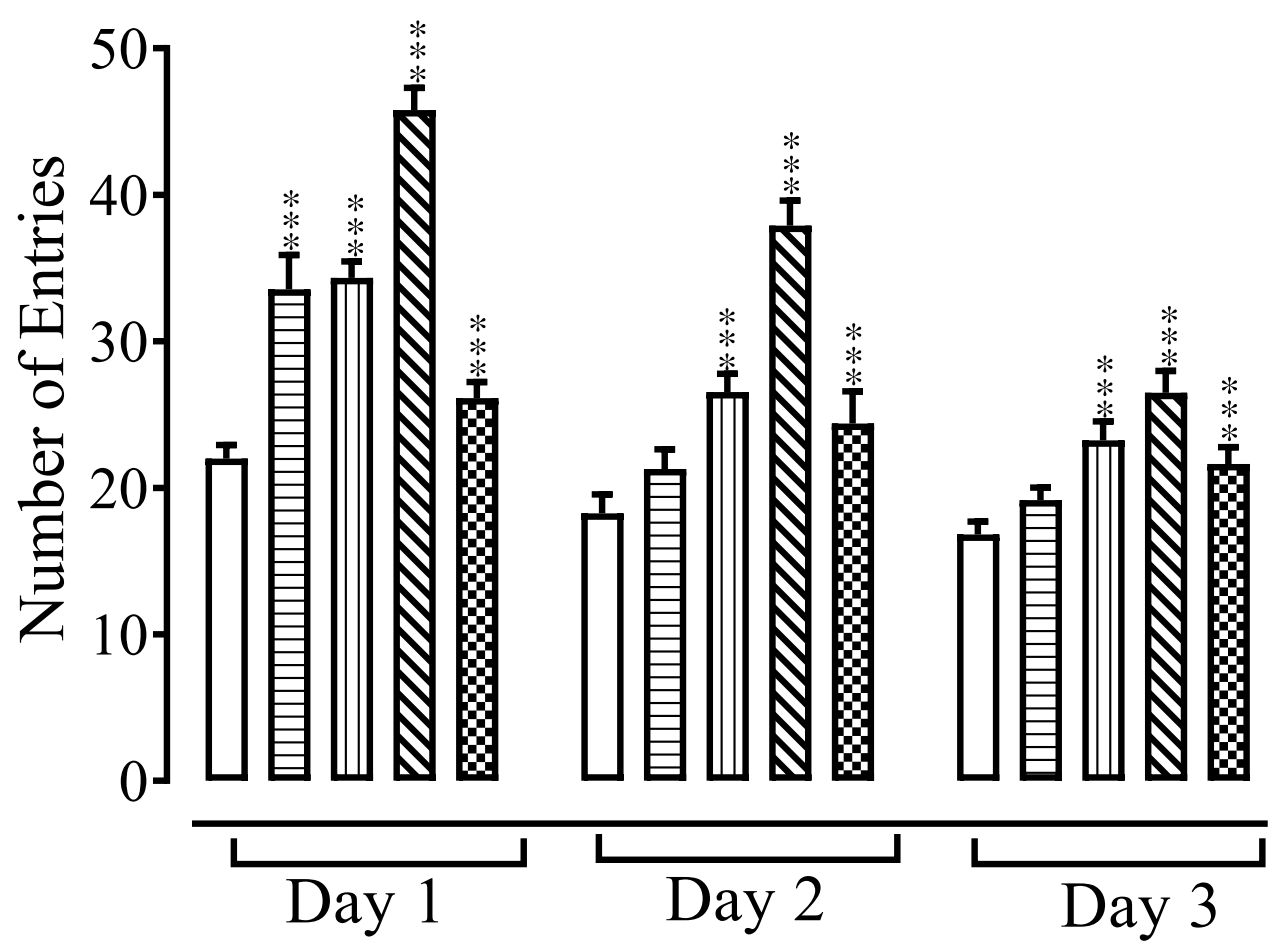

Figure 7 Bar chart showing effect of (E)-2-(4-methoxybenzylidene)cyclopentan-I-one (A2KI0) and donepezil on number of mouse entries in the Y-maze test on days I, 2, and 3. Data presented as means $\pm \mathrm{SEM}, \mathrm{n}=5$. $*_{* *} p<0.00$ I vs saline group on one-way ANOVA with Tukey's post hoc test.

\pm 0.81 seconds ( $p<0.001$ vs haloperidol group), respectively. In the A2K10 (3 mg/kg)-injected group, hanging time on the first and eighth days had increased to $9.4 \pm 0.45$ and $17.3 \pm 0.70$ seconds ( $p<0.001$ vs haloperidol group), respectively. In the $\mathrm{A} 2 \mathrm{~K} 10$ (10 $\mathrm{mg} / \mathrm{kg})$-injected group, hanging time on the first and eighth days had increased to $11.1 \pm 0.93$ and $20.7 \pm 0.66$ seconds ( $p<0.001$ vs haloperidol group), respectively. In the group treated with levodopa $(30 \mathrm{mg} / \mathrm{kg})$, hanging time on the first and eighth day had increased to $18.8 \pm 1.69$ and $21.0 \pm 0.55$ seconds ( $p<0.001$ vs haloperidol group), respectively (Figure 9).

\section{Effect on VCMs}

A2K10 had dose-dependently (1-10 mg/kg) decreased VCMs in mice by the eighth day of experiment. The group treated with saline $(10 \mathrm{~mL} / \mathrm{kg})$ showed $7.2 \pm 0.37$ and $6.4 \pm 0.51 \mathrm{VCMs}$ on the first and eighth days, respectively. The group treated with haloperidol $(1 \mathrm{mg} / \mathrm{kg})$ showed $46.2 \pm 1.20$ and $70.6 \pm 0.93$ ( $p<0.001$ vs saline group) VCMs on the first and eighth days, respectively. In the $\mathrm{A} 2 \mathrm{~K} 10(1 \mathrm{mg} / \mathrm{kg})$ group, VCMs on the first and eighth days had reduced to $45.6 \pm 1.21$ and $36.6 \pm 0.93$ ( $p<0.001$ vs haloperidol group), respectively. In the A2K10 (3 $\mathrm{mg} / \mathrm{kg}$ ) group, VCMs on the first and eighth days had reduced to $44.2 \pm 1.28$ and $22.4 \pm 0.93$ ( $p<0.001$ vs haloperidol group), respectively. In the A2K10 (10 mg/kg)-injected group, VCMs on the first and eighth days had reduced to $43.8 \pm 1.16$ and 13.4 \pm 0.93 ( $p<0.001$ vs haloperidol group), respectively. In the levodopa (30 mg/kg)-injected group, VCMs on the first and eighth days had reduced to $14.8 \pm 0.97$ and $11.2 \pm 0.66(p<0.001$ vs haloperidol group), respectively (Figure 10).

\section{Effect on Hot-Plate Nociception}

A2K10 dose-dependently (1-10 $\mathrm{mg} / \mathrm{kg})$ increased the escape latency of mice on hot-plate assays. The group 


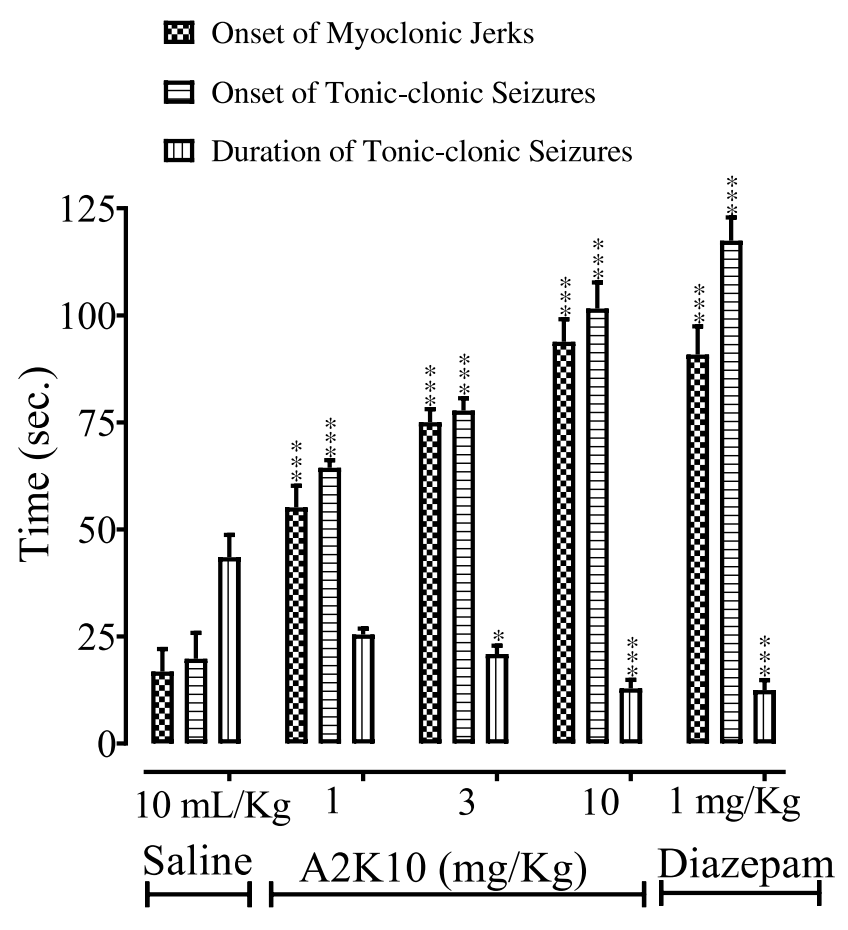

Figure 8 Bar chart showing effects of (E)-2-(4-methoxybenzylidene)cyclopentan-Ione (A2KI0) and diazepam on onset of pentylenetetrazole (Ptz)-induced myoclonic jerks, tonic-clonic seizures, and duration of tonic-clonic seizures in mice. Data presented as means \pm SEM $(n=5) .{ }^{*} p<0.05$, ${ }^{* * *} p<0.001$ vs saline group on one-way ANOVA with Tukey's post hoc test.

treated with saline $(10 \mathrm{~mL} / \mathrm{kg})$ showed latency to thermal sensitivity at days $0,8,12,16,20$, and 24 of $17.5 \pm 1.07$, $21.2 \pm 0.32,16.4 \pm 0.60,18.4 \pm 0.53,20.6 \pm 0.45$, and 19.4 \pm 0.51 seconds, respectively. In the cisplatin $(5 \mathrm{mg} / \mathrm{kg}$ )injected group, latency had reduced to $16.7 \pm 1.16$ ( $p<0.001$ vs saline group), $6.2 \pm 0.76(p<0.001$ vs saline group), $\quad 5.4 \pm 0.58 \quad(p<0.001$ vs saline group $), 4 \pm 0.34$ ( $p<0.001$ vs saline group), $3.3 \pm 0.34(p<0.001$ vs saline group), and $2.8 \pm 0.25$ seconds ( $p<0.001$ vs saline group), respectively. In the group treated with A2K10 $(1 \mathrm{mg} / \mathrm{kg})$, latency had increased to $17.0 \pm 1.18,6.7 \pm 0.75(p<0.001$ vs

Table 4 Effect of (E)-2-(4-methoxybenzylidene)cyclopentan-Ione (A2K10) and Diazepam on Pentylenetetrazole (Ptz)Induced Seizure Mortality in Mice

\begin{tabular}{|l|l|}
\hline Group & $\%$ Mortality \\
\hline Saline $(10 \mathrm{~mL} / \mathrm{kg})+$ Ptz $(90 \mathrm{mg} / \mathrm{kg})$ & 100 \\
A2K $10(1 \mathrm{mg} / \mathrm{kg})+$ Ptz $(90 \mathrm{mg} / \mathrm{kg})$ & $80^{* * *}$ \\
A2K $10(3 \mathrm{mg} / \mathrm{kg})+$ Ptz $(90 \mathrm{mg} / \mathrm{kg})$ & $60^{* * *}$ \\
A2K $10(10 \mathrm{mg} / \mathrm{kg})+$ Ptz $(90 \mathrm{mg} / \mathrm{kg})$ & $20^{* * *}$ \\
Diazepam $(1 \mathrm{mg} / \mathrm{kg})+$ Ptz $(90 \mathrm{mg} / \mathrm{kg})$ & $0 * * *$ \\
\hline
\end{tabular}

Notes: \% Mortality $=$ (number of mice dead after convulsions/total number of mice used) $\times 100, n=5 . * * p<0.01, * * * p<0.001$ vs saline group on one-way ANOVA followed by Tukey's post hoc test.

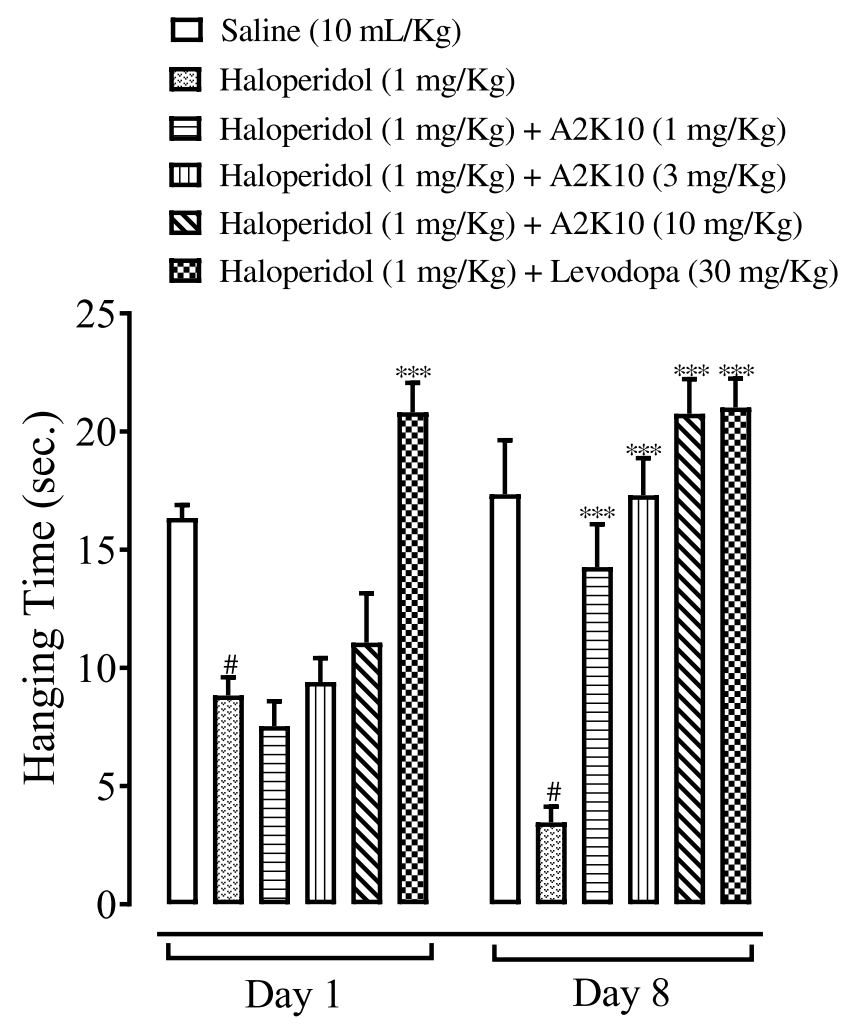

Figure 9 Bar chart showing effects of (E)-2-(4-methoxybenzylidene)cyclopentan- Ione $(\mathrm{A} 2 \mathrm{~K} 10)$ and levodopa on hanging time of mice in haloperidol-induced Parkinson's disease (PD). Data presented as means \pm SEM $(n=5) . \# p<0.001$ vs saline group and $* * * *<0.001$ vs haloperidol group on one-way ANOVA with Tukey's post hoc test.

cisplatin group), $5.9 \pm 0.78,6.1 \pm 0.56,5.7 \pm 0.27$, and 5.4 \pm 0.24 seconds, respectively. In the A2K10 (3 mg/kg) group, latency had increased to $16.8 \pm 0.72,7.0 \pm 0.73,8.7$ $\pm 0.72,11.0 \pm 0.58(p<0.001$ vs cisplatin group), $11.8 \pm 0.61$ ( $p<0.001$ vs cisplatin group), and $12.4 \pm 0.64$ seconds ( $p<0.001$ vs cisplatin group), respectively. In the A2K10 $(10 \mathrm{mg} / \mathrm{kg})$ group, latency had increased to $18.0 \pm 0.72,8.3$ $\pm 0.26,9.3 \pm 0.64$ ( $p<0.001$ vs cisplatin group), $11.7 \pm 0.65$ ( $p<0.001$ vs cisplatin group), $12.9 \pm 0.57$ ( $p<0.001$ vs cisplatin group), and $15.3 \pm 0.68$ seconds ( $\mathrm{p}<0.001$ vs cisplatin group), respectively. In the tramadol $(30 \mathrm{mg} / \mathrm{kg})$-injected group, latency had increased to $18.1 \pm 0.47,10.6 \pm 0.70$ ( $p<0.001$ vs cisplatin group), $11.1 \pm 0.74(p<0.001$ vs cisplatin group), $12.1 \pm 0.65$ ( $p<0.001$ vs cisplatin group), 14.3 \pm 0.70 ( $p<0.001$ vs cisplatin group), and $17.1 \pm 0.45$ seconds $(p<0.001$ vs cisplatin group), respectively (Figure 11).

\section{Effect on Paw-Withdrawal Threshold}

A2K10 dose-dependently (1-10 mg/kg) suppressed cisplatin-induced mechanical allodynia. The group treated with saline $(10 \mathrm{~mL} / \mathrm{kg})$ showed PWT at days $0,8,12,16,20$, and 24 of $2 \pm 0,2 \pm 0,2 \pm 0,2 \pm 0,2 \pm 0$, and $2 \pm 0 \mathrm{~g}$, 

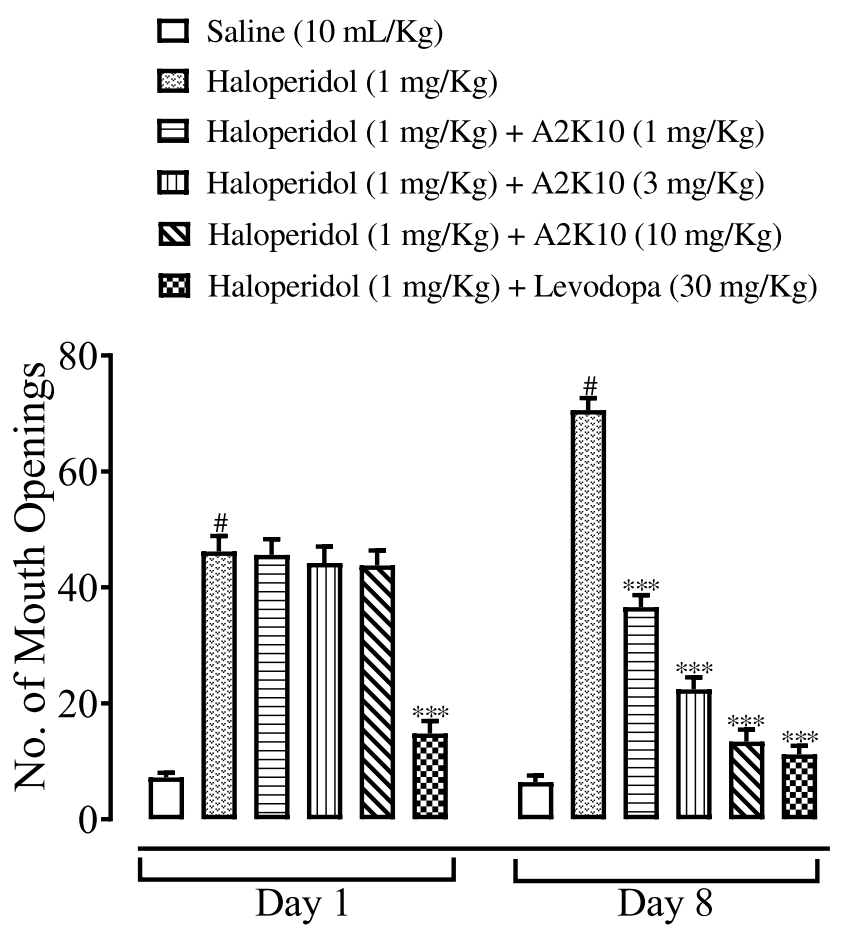

Figure 10 Bar chart showing effects of (E)-2-(4-methoxybenzylidene)cyclopentan$\mathrm{I}$-one $(\mathrm{A} 2 \mathrm{~K} 10)$ and levodopa on number of mouth openings in haloperidol-induced Parkinson's disease (PD) model in mice. Data presented as means \pm SEM $(n=5)$. ${ }^{\#} p<0.00$ I vs saline group and ${ }^{* * *} p<0.001$ vs haloperidol group on one-way ANOVA with Tukey's post hoc test.

respectively. In the cisplatin $(5 \mathrm{mg} / \mathrm{kg})$-injected group, mechanical PWT had reduced to $2 \pm 0(p<0.001$ vs saline group), $1.4 \pm 0.15$ ( $p<0.001$ vs saline group $), 0.9 \pm 0.08$ ( $p<0.001$ vs saline group), $0.6 \pm 0.06$ ( $p<0.001$ vs saline group), $0.6 \pm 0.06$ ( $\mathrm{p}<0.001 \mathrm{vs}$ saline group), and $0.3 \pm 0.05$ $\mathrm{g}(p<0.001$ vs saline group) $\mathrm{g}$, respectively. In the A2K10 $(1 \mathrm{mg} / \mathrm{kg})$ group, mechanical PWT had increased to $2 \pm 0$, $1.2 \pm 0.08,0.9 \pm 0.11,0.9 \pm 0.11,0.9 \pm 0.08$, and $0.6 \pm 0.08 \mathrm{~g}$, respectively. In the A2K10 $(3 \mathrm{mg} / \mathrm{kg})$ group, mechanical PWT had increased to $2 \pm 0,1.1 \pm 0.1,0.9 \pm 0.14,1 \pm 0.1$ ( $p<0.01$ vs cisplatin group), $1.1 \pm 0.1$, and $0.7 \pm 0.08 \mathrm{~g}$, respectively. In the $\mathrm{A} 2 \mathrm{~K} 10(10 \mathrm{mg} / \mathrm{kg})$ group, mechanical PWT had further increased to $2 \pm 0,1.2 \pm 0.08,1.2 \pm 0,1.2$ $\pm 0.11,1.3 \pm 0.13$ ( $p<0.001$ vs cisplatin group), and $1.5 \pm 0.06$ $\mathrm{g}(p<0.001 \mathrm{vs}$ cisplatin group), respectively. In the tramadol (30 mg/kg)-injected group, mechanical PWT was $2 \pm 0$, $1.3 \pm 0.1$ ( $p<0.001$ vs cisplatin group), $1.9 \pm 0.06(p<0.001$ vs cisplatin group), $1.9 \pm 0.06$ ( $p<0.001$ vs cisplatin group), $1.9 \pm 0.06(p<0.001$ vs cisplatin group), and $1.9 \pm 0.05$ $(p<0.001$ vs cisplatin group) g, respectively (Figure 12).

\section{Acute Toxicity}

A2K10 caused no mortality at a dose of $500 \mathrm{mg} / \mathrm{kg}$.

\section{Discussion}

This study was performed to investigate docking, anti-AD, antiepileptic, anti-PD, and analgesic effects of A2K10 in mice. An important component of drug-discovery programs is computational analysis. The $\mathrm{n}$ silico analytical tool PatchDock was used to assess the binding affinity of A2K10, taking into consideration ACE values, number of hydrogen bonds, and amino-acid residues forming hydrogen bonds against protein targets. Depending upon the ACE values and number of hydrogen bonds, postdocking analysis revealed a binding-affinity order of A2K10 against target proteins involved in $\mathrm{AD}$ of NMDA > COMT $>$ AChE $>$ BACE $>$ BuChE. Among target proteins interceding epilepsy, the ligand receptor-affinity order was $\mathrm{GABA}_{\mathrm{A}}>$ Orai $>$ DUSP13. GABA $\mathrm{A}$ has good binding affinity. The ligand's order of binding affinity against PD-associated receptors was $\mathrm{M}_{1}>\mathrm{H}_{1}>\mathrm{D}_{2}>$ $\mathrm{GABA}_{\mathrm{B}}$. Computational analysis of $\mathrm{A} 2 \mathrm{~K} 10$ was also carried out against receptors involved in pain. The order of binding affinity was $\alpha_{7} \mathrm{nAChR}>\mathrm{TNF} \alpha>\mathrm{TLR} 4>\mathrm{PPAR} \gamma$ $>\operatorname{COX} 2>\alpha_{4} \beta_{2}>$ PLA2. $\alpha_{7}$ nAChR had the maximum ACE value with no hydrogen bond.

DPPH assays were used to check antioxidant potential. Discoloration of the solution indicated the DPPH free radical-scavenging effect. Studies have shown that the free radical-scavenging mechanism depends upon the hydroxyl groups present on the antioxidant molecule. Increased DPPH free radical-scavenging activity showed antioxidant properties. ${ }^{16}$ A2K10 showed a slight increase in DPPH free radical-scavenging effect.

In order to study anti-AD activity, MWM and Y-maze tests were used. ${ }^{10,11}$ Memory impairment can be due to neurodegeneration in hippocampus and presence of amyloid plaques in the hippocampus of the brain. Spontaneous alteration behavior was studied to check memory. Enhanced cognitive performance is associated with increased of spontaneous alteration behavior. ${ }^{11}$ A2K10 dose-dependently increased the number of entries and spontaneous alteration behavior of mice in the Y-maze test. Anti-AD activity of A2K10 was revealed by its dose-dependent increase in escape latency in the MWM. Mostly neurofibrillary lesions, $\beta$-amyloid plaques, inflammatory processes, acetylcholine deficiency, and damaged cholinergic neurons are involved in $\mathrm{AD} .{ }^{17} \mathrm{~A} 2 \mathrm{~K} 10$ possesses good binding affinity against NMDA receptors, and studies have shown that memory and learning can be enhanced by blockade of NMDA receptors. ${ }^{18}$ 


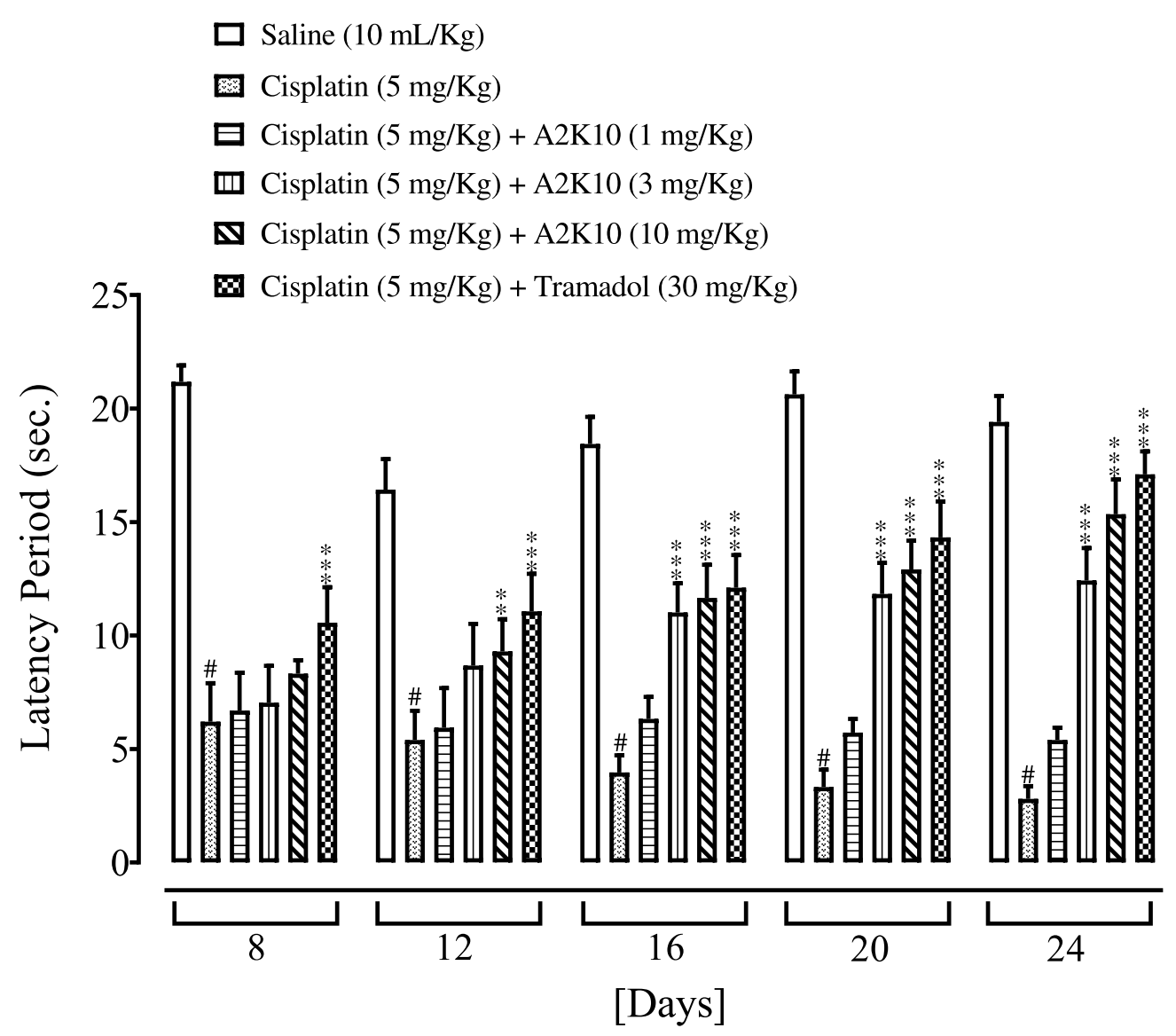

Figure II Bar chart showing effects of (E)-2-(4-methoxybenzylidene)cyclopentan-I-one (A2KI0) and tramadol on mouse escape latency in cisplatin-induced neuropathic pain. Data presented as means \pm SEM $(n=5) .{ }^{*} p<0.001$ vs saline group and $*^{*} p<0.01$ and $*^{* * *} p<0.001$ vs cisplatin group on one-way ANOVA with Tukey's post hoc test.

In accordance with the in silico studies, the antiepileptic action of $\mathrm{A} 2 \mathrm{~K} 10$ can be due to the mechanism of $\mathrm{GABA}_{\mathrm{A}}$ activation. Valproic acid is the main antiepileptic drug that mainly inhibits sodium channels and increases brain levels of GABA. GABAergic neurons in the thalamus are mainly involved in the control of seizures. Ptz is a $\mathrm{GABA}_{\mathrm{A}}$ (inhibitory neurotransmitter) antagonist that induces seizures by reducing GABAergic neurotransmission. ${ }^{19}$ A2K10 caused dose-dependent delays in the onset of myoclonic and tonic-clonic convulsions, along with a reduction in the duration of tonic-clonic convulsions and decreased mortality of mice. A2K10 showed lower antiepileptic activity compared to diazepam, suggesting that antiepileptic action of the test compound was possibly due to the activation of $\mathrm{GABA}_{\mathrm{A}}$ receptors.

In silico studies showed that $\mathrm{M} 1$ and $\mathrm{H}_{1}$ were binding sites that might be involved in the anti-PD effect of A2K10. $\mathrm{PD}$ is characterized mainly by the degeneration of neurons in the substantia nigra of brain accompanied by reduced dopamine release and movement disorders, including tremors and slow movement. Haloperidol is an antipsychotic drug that induces PD by blocking dopamine receptors, resulting in dopamine turnover followed by oxidative stress. ${ }^{20}$ The hanging test was used to check neuromuscular strength, and A2K10 dose-dependently increased the hanging timeand reduced VCMs in mice. Studies have shown that the cholinergic system is involved in maintaining functioning of basal ganglia, and muscarinic antagonists were used in PD treatment. ${ }^{21}$ A2K10 showed more effect compared to levodopa which may be due to binding affinity with NMDA and $\mathrm{M}_{1}$ receptors. $\alpha_{7} \mathrm{nAChR}, \operatorname{PPAR} \gamma, \mathrm{TNF} \alpha$, and COX2 were the main sites with good binding affinity, so they might be involved in the analgesic effect of A2K10. Cisplatin is involved in most types of tumors. Among common chemotherapeutic drugs used in cancer chemotherapy, it has good therapeutic efficacy against many agents. Platinumbased drugs in particular have a dose-limiting side effect known as chemotherapy-induced neuropathic pain. Painful sensory neuropathy produced in the distal extremities are mainly produced by platinum-based drugs, ie cisplatin and oxaliplatin. ${ }^{22}$ Production of proinflammatory cytokines is modulated by the activation of $\alpha_{7} \mathrm{nAChR},{ }^{23}$ and antinociception to acute mechanical and thermal stimuli can be produced 


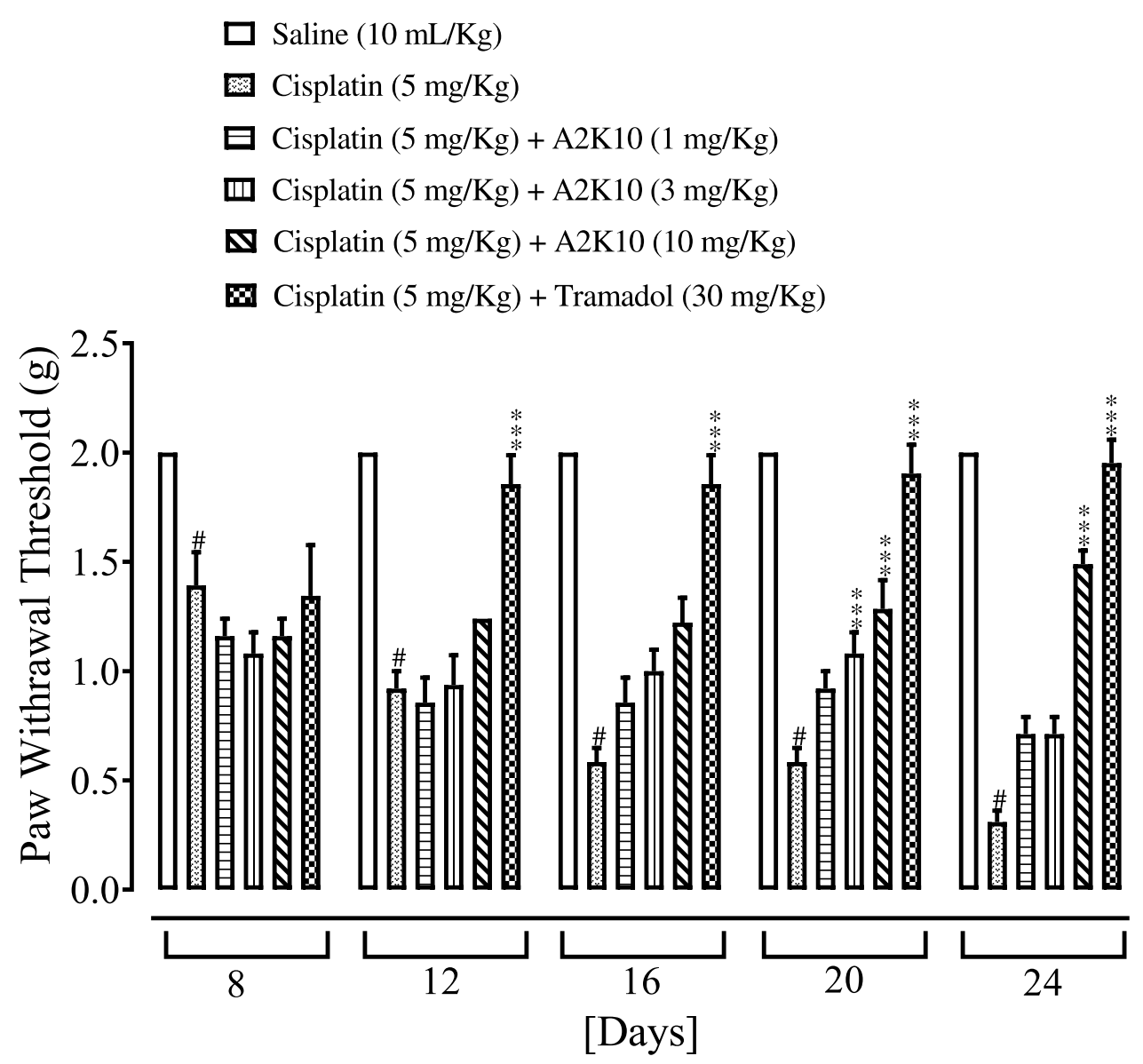

Figure 12 Bar chart showing effects of (E)-2-(4-methoxybenzylidene)cyclopentan-I-one (A2KI0) and tramadol on mouse paw-withdrawal threshold in cisplatin-induced neuropathic pain. Data presented as means \pm SEM $(n=5)$. ${ }^{*}<<0.00$ I vs saline group and $* * * p<0.00$ I vs cisplatin group on one-way ANOVA with Tukey's post hoc test.

by these receptors. ${ }^{24}$ PPAR $\gamma$ agonists are involved in the reduction of neuropathic pain by inhibiting expression of chemokines that are inflammatory mediators. ${ }^{25}$ Prostaglandins produced by COX2 play an important role in enhancing pain and inflammation. Therefore, pain and inflammation can be reduced by blocking COX 2 receptors. ${ }^{26}$

\section{Conclusion}

The present study reveals that $\mathrm{A} 2 \mathrm{~K} 10$ possesses high affinity against $\alpha_{7} \mathrm{nAChR}, \mathrm{NMDA}, \mathrm{M}_{1}$, and $\mathrm{GABA}_{\mathrm{A}}$ targets. In vitro and in vivo investigation revealed its antioxidant, antiepileptic, and analgesic effects, with positive responses against memory and cognitive deficits as well. As such, the therapeutic potential of A2K10 in various neurological disorders should be explored.

\section{Acknowledgments}

We are grateful to Dr Zia Ud Din for the gift of A2K10. We are thankful to Dr Muzaffar Abbas for his valuable guidance and Komal Naeem for her editorial cooperation.

\section{Disclosure}

The authors report no conflicts of interest for this work.

\section{References}

1. Sarfo SS, Akassi J, Badu E, et al. Profile of neurological disorders in an adult neurology clinic in Kumasi, Ghana. J Neurol Sci. 2016;3:6974.

2. Bales KR, Tzavara ET, Wu S, et al. Cholinergic dysfunction in a mouse model of Alzheimer disease is reversed by an anti-abantibody. $J$ Clin Invest. 2006;116(3):825-832. doi:10.1172/JCI27120

3. Saxena S, Li S. Defeating epilepsy: a global public health commitment. Epilepsia Open. 2017;2(2):153-155. doi:10.1002/epi4.12010

4. Abbas MM, Xu Z, Tan LCS. Epidemiology of Parkinson's disease-east versus west. Mov Disord Clin Pract. 2017;5(1):14-28. doi:10.1002/ mdc 3.12568

5. Lin H, Heo BH, Yoon MH. A new rat model of cisplatin induced neuropathic pain. Korean J Pain. 2015;28(4):236-243. doi:10.3344/ kjp.2015.28.4.236

6. Yeung AWK, Horbańczuk M, Tzvetkov NT, et al. Curcumin: totalscale analysis of the scientific literature. Molecules. 2019;24(7):1393. doi: $10.3390 /$ molecules 24071393

7. Din ZU, Filho ER. Optimized one-pot synthesis of monoarylidene and unsymmetrical diarylidene cycloalkanones. Arab J Chem. 2016.

8. National Research Council. Guide for the Care and Use of Laboratory Animals. Washington: National Academy Press; 1996. 1-7. 
9. Kumar S, Kumar V, Chandrashekhar MS. In vitro anti-oxidant and alpha-amylase inhibitory activity of isolated fractions from methanolic extract of Asystasiadalzelliana leaves. Int J Pharmtech Res. 2011;3:889-894.

10. Morris R. Developments of a water-maze procedure for studying spatial learning in the rat. $J$ Neurosci Methods. 1984;1984(11):4760. doi:10.1016/0165-0270(84)90007-4

11. Ali T, Badshah H, Kim TH, et al. Melatonin attenuates D-galactoseinduced memory impairment, neuroinflammation and neurodegeneration via $\mathrm{RAGE} / \mathrm{NF}-\mathrm{KB} / \mathrm{JNK}$ signaling pathway in aging mouse model. J Pineal Res. 2015;58(1):71-85. doi:10.1111/jpi.12194

12. Bum EN, Ngoupaye GT, Talla E, et al. The anticonvulsant and sedative properties of stems of Cissusquadrangularis in mice. Afr $J$ Pharm Pharmacol. 2008;2:42-47.

13. Bagewadi HG, Khan A. Investigation of antiparkinsonian effect of Aloe vera on haloperidol induced experimental animal model. Indian J Pharm Biol Res. 2015;3(01):108-113. doi:10.30750/ijpbr.3.1.15

14. Marcus DJ, Zee M, Hughes A, et al. Tolerance to the antinociceptive effects of chronic morphine requires c-Jun N-terminal kinase. Mol Pain. 2015;11:15-31. doi:10.1186/s12990-015-0031-4

15. Baghel SS, Dangi S, Soni P, et al. Acute toxicity study of aqueous extract of Cocciniaindica (roots). Asian J Res Pharm Sci. 2011;1:2325.

16. Mensor LL, Menezes FS, Leitao GG, et al. Screening of Brazilian plant extracts for antioxidant activity by the use of DPPH free radical method. Phytother Res. 2001;15(2):127-130. doi:10.1002/ptr.687

17. Lee GY, Lee C, Park GH, et al. Amelioration of scopolamine-induced learning and memory impairment by pinene in C57BL/6 mice. Evid Based Complementary Altern Med. 2017;1:1-9.

18. Li F, Tsien JZ. Memory and the NMDA receptors. $N$ Engl J Med. 2009;361(3):302-303. doi:10.1056/NEJMcibr0902052
19. Okada R, Negishi N, Nagaya H. The role of the nigrotegmental GABAergic pathway in the propagation of pentylenetetrazol-induced seizures. Brain Res. 1989;480(1-2):383-387. doi:10.1016/0006-8993 (89)90212-6

20. Saeed A, Shakir L, Khan MA, et al. Haloperidol induced Parkinson's disease mice model and motor-function modulation with pyridine-3carboxylic acid. Biomed Res Ther. 2017;4(05):1305-1317. doi:10.15419/bmrat.v4i05.169

21. Xiang Z, Thompson AD, Jones CK, et al. Roles of the M1 muscarinic acetylcholine receptor subtype in the regulation of basal ganglia function and implications for the treatment of Parkinson's disease. $J$ Pharmacol Exp Ther. 2011;340(3):595-603. doi:10.1124/jpet.111. 187856

22. Joseph EK, Levine JD. Comparison of oxaliplatin- and cisplatininduced painful peripheral neuropathy in the rat. J Pain. 2009;10 (5):534-541. doi:10.1016/j.jpain.2008.12.003

23. Jonge WD, Ulloa L. The alpha7 nicotinic acetylcholine receptor as a pharmacological target for inflammation. Br J Pharmacol. 2007;151 (7):915-929. doi:10.1038/sj.bjp.0707264

24. Gurun MS, Parkar R, Eisenach JC, et al. The effect of peripherally administered CDP-choline in an acute inflammatory pain model: the role of $\alpha 7$ nicotinic acetylcholine receptor. Int Anaesth Res Soc. 2009;108:1680-1687.

25. Freitag CM, Miller RJ. Peroxisome proliferator-activated receptor agonists modulate neuropathic pain: a link to chemokines? Front Cell Neurosci. 2014;8:238. doi:10.3389/fncel.2014.00238

26. Zarghi A, Arfaei S. Selective COX-2 inhibitors: a review of their structure-activity relationships. Iran J Pharm Res. 2011;10(4):655683

\section{Publish your work in this journal}

Drug Design, Development and Therapy is an international, peerreviewed open-access journal that spans the spectrum of drug design and development through to clinical applications. Clinical outcomes, patient safety, and programs for the development and effective, safe, and sustained use of medicines are a feature of the journal, which has also been accepted for indexing on PubMed Central. The manuscript management system is completely online and includes a very quick and fair peer-review system, which is all easy to use. Visit http://www. dovepress.com/testimonials.php to read real quotes from published authors. 